\title{
ACADEMIC FREEDOM IN THE BRAZILIAN CONSTITUTIONAL HISTORY
}

\section{LIBERDADE DE CÁTEDRA NA HISTÓRIA CONSTITUCIONAL BRASILEIRA}

\author{
Diego Nunes \\ Universidade Federal de Santa Catarina (Brasil)
}

\begin{abstract}
SUMARIO: I. INTRODUCTION. - II. FREEDOM OF SPEECH AND ACADEMIC FREEDOM IN THE FIRST BRAZILIAN CONSTITUTIONS (EMPIRE AND FIRST REPUBLIC). - III. ACADEMIC FREEDOM IN THE CONSTITUTION OF 1934. - IV. ACADEMIC FREEDOM BETWEEN AUTHORITARIANISM AND DEMOCRACY: CONSTITUTIONS OF 1937, 1946, 1967 AND 1969. - V. DEVELOPMENTS OF ACADEMIC FREEDOM IN THE BRAZILIAN CONSTITUTIONAL THOUGHT. - VI. CONCLUSION.
\end{abstract}

Abstract: This work aims to analyse the principle of academic freedom in Brazilian constitutionalism, throught the lens of Legal History, to understand when this specific rule became part of the set of fundamental rights in Brazil. To do this I will present the parliamentary debates in the Constitutional Assembly in 1934 when it was first mentioned, and the thoughts of certain legal scholars on the subject in the comments on Brazilian constitutions. As results, I present some contemporary issues where this historical approach can be useful.

Resumo: O artigo tem como objetivo analisar o princípio da liberdade de cátedra no constitucionalismo brasileiro, pelo olhar da história do direito, para compreender quando esta regra específica tornou-se parte do rol de direitos fundamentais no Brasil. Para isso apresentam-se os debates parlamentares nos anais da assembleia constituinte de 1934, quando ele foi pela primeira vez mencionado, e os argumentos de alguns doutrinadores sobre o tema em comentários às constituições brasileiras. Como resultado, apresenta-se algumas questões contemporâneas em que a abordagem histórica apresenta-se útil.

Key Words: Academic Freedom - Constitutionalism - Fundamental Rights Constitutional History - Legal History - Brazil (XIX-XX Century)

Palavras-chave: Liberdade de Cátedra - Constitucionalismo - Direitos Fundamentais - História Constitucional - História do Direito - Brasil (séculos XIX-XX). 


\section{INTRODUCTION}

Notoriously, Brazil is currently living an expressive debate on freedom of speech since the general electoral process and the rising of the right-wing in power, especially with president Bolsonaro ${ }^{1}$.

However, since a year before we already have lived great problems on academic freedom. Three years ago, the rector of the Federal University of Santa Catarina, one of the five most important athenaeum in Brazil, was arrested with charges of budgeting issues. After a habeas corpus he committed suicide and subsequent investigations have proving his innocence. In his celebration, a new act against abuse of power received his name ${ }^{2}$.

Another harsh episode was when an elected Representative of the State of Santa Catarina called students to record teachers and professors in schools and universities, after Bolsonaro's victory, in order to curb left-wing speeches and fight against 'cultural Marxism'3.

Since then, academics are studying the issue in Brazil in many ways ${ }^{4}$. My proposal is look at these phenomena through the lens of Legal History. The goal is to make an overview of academic freedom (and similar) in the Brazilian constitutions. We will see the moment when this specific rule became part of the set of fundamental rights in Brazil. Here I will also present the parliament debates in the Constitutional Assembly in its first mention in 1934. After that, I shall put forward what some legal scholars have written in their comments on Brazilian constitutions. In the end, I will bring up some contemporary questions where this historical approach can be useful.

\section{FREEDOM OF SPEECH AND ACADEMIC FREEDOM IN THE FIRST BRAZILIAN CONSTITUTIONS (EMPIRE AND FIRST REPUBLIC)}

The first Brazilian constitution was born in the imperial age (1822-1889) in 1824. The first draft was designed by the General Assembly; however, Emperor Peter I closed these works in virtue of conflicts on the authority of monarchy in the text. He had nominated a commission of jurists to elaborate a constitution

1 "From now on, we will be guided by the sovereign will of those Brazilians who want good schools, capable of preparing their children for the labor market and not for political militancy" in "Address by the President of the Republic, Jair Bolsonaro, after being sworn in as President of the Republic and the National Congress". Presidency of the Republic of Brazil, 01.01.2019, in http:/ / www.brazil.gov.br/government/speeches/2019/01/address-by-the-president-of-therepublic-jair-bolsonaro-after-being-sworn-in-as-president-of-the-republic-and-the-nationalcongress.

2 See the speeches on the "Lei Cancelier" in National Congress at https://www.camara.leg.br/proposicoesWeb/fichadetramitacao?idProposicao=2136580. Also, the article by Justice Gilmar Mendes of Brazilian Federal Supreme Court in "Abuso de Autoridade e o reencontro com o Estado de Direito", in Conjur, 03.01.2020, in https://www.conjur.com.br/2020-jan-03/opiniao-lei-cancellier-zavaski-lei-abuso-autoridade.

3 "Snitch on a teacher: Bolsonaro win sparks push against 'indoctrination'". The Guardian, 30.10.2018, in https://www.theguardian.com/world/2018/oct/30/bolsonaro-win-studentsurged-report-teachers-who-complain-whatsapp.

4 See, for example, Carolina Cyrillo, Luiz Fernando Castilhos Silveira, 'A autonomia universitária na Constituição de 1988: um modelo de autonomia institucional em construção", Revista Práticas em Gestão Pública Universitária, a. 5, v. 5, n. 1, jan.-jun., 2021, pp. 82-104.] 
"even more liberal than the representatives' project." We can say "the monarchical constitution was basically a liberal-conservative arrangement, similar to the French charter of 1815 and the Belgian constitution of $1831 " 5$.

The article 179 of Imperial Constitution (CI/1824) had been settled the fundamental rights in the country. In para. IV. was established "All [citizens] shall communicate their thoughts, by words or writings, and publish them by the Press, without dependence of censorship; with so much that they will respond for the abuses perpetrated in the exercise of this Right, in the cases, and by the form, that the Law determines" In the para. XXXIII., "[The Constitution also guarantees the] Colleges and Universities, where will be taught elements of Sciences, Literature and Arts."6

Before the independence act, during the United Kingdom of Portugal, Brazil and Algarves the Decree of June 18, 1822 had created the jury to process press crimes based on the "supreme law of pubic salvation" against the "enemies of order, tranquillity and union" and their "inflammatory and subversive doctrines" 7 . This rule is interesting because it establishes successive responsibility of editors and publishers, generally described by doctrine as a Belgian invention ${ }^{8}$.

More specific about academic freedom was the Act of August 11, 1827. This law created the courses of Legal and Social Sciences at São Paulo and Olinda (after Recife). The Parliament decided on Article 7 that the lectures (Lentes) would choose the handbooks (compendios) or make them. However, General Assembly imposed as a condition that doctrines taught would be in accord to a "national system" (constitutional monarchy) and demanded that this verification would be

\footnotetext{
5 José Reinaldo de Lima Lopes, "Brazil”, en S. Katz y W. Menski (edit.), Oxford International Encyclopedia of Legal History, OUP, London \& New York, 2009.

6 CI/1824: "Art. 179. A inviolabilidade dos Direitos Civis, e Politicos dos Cidadãos Brazileiros, que tem por base a liberdade, a segurança individual, e a propriedade, é garantida pela Constituição do Imperio, pela maneira seguinte. [...] IV. Todos podem communicar os seus pensamentos, por palavras, escriptos, e publical-os pela Imprensa, sem dependencia de censura; com tanto que hajam de responder pelos abusos, que commetterem no exercicio deste Direito, nos casos, e pela fórma, que a Lei determinar. [...] XXXIII. Collegios, e Universidades, aonde serão ensinados os elementos das Sciencias, Bellas Letras, e Artes", in http://www.planalto.gov.br/ccivil_03/constituicao/constituicao24.htm.
}

7 "Decreto de 18 de junho de 1822. Crêa Juizes de Facto para julgamento dos crimes de abusos de liberdade de imprensa": "cumpria-Me necessariamente e pela suprema lei da salvação publica evitar que ou pela imprensa, ou verbalmente, ou de outra qualquer maneira propaguem e publicquem os inimigos da ordem e da tranquillidade e da união, doutrinas incendiarias e subversivas, principios desorganizadores e dissociaveis; que promovendo a anarchia e a licença, ataquem e destruam o systema, que os Povos deste grande e riquissimo Reino por sua propria vontade escolheram [...] E para que o Procurador da Corôa e Fazenda tenha conhecimento dos delictos da imprensa, serão todas as Typographias obrigadas a mandar um exemplar de todos os papeis, que se imprimirem. Todos os escriptos deverão ser assignados pelos escriptores para sua responsabilidade: e os editores ou impressores, que imprimirem e publicarem papeis anonymos, são responsaveis por elles. Os auctores porém de pasquins, proclamações incendiarias, e outros papeis não impressos serão processados e punidos na fórma prescripta pelo rigor das leis antigas", in http://www.planalto.gov.br/ccivil_03/decreto/historicos/dim/DIM-18-6-1822-2.htm.

8 Roberto Lyra, Introdução ao estudo do direito criminal, Nacional, Rio de Janeiro, 1946, p. 89; Heleno Claudo Fragoso, Lições de Direito Penal, Forense, Rio de Janeiro, [1958] 2006, p. 72. 
performed preliminary by the Academic Senate (Congregação) and after that by a chamber of parliament (Câmara dos Deputados) ${ }^{9}$.

The liberal representatives would concede to the professor the right to choose the handbooks, while the conservatives would have granted themselves control of the books in Law courses. The result was a ruleset that was at the same time ambiguous and centralized ${ }^{10}$.

Recent research on the foundation of legal courses in Brazil attributes the education based in the use of handbooks controlled by political powers as a Portuguese system and an unusual conservative heritage in those times of national state-building. ${ }^{11}$

In this regard, Sonia Oliveira ${ }^{12}$ has been studying Brazilian lawyers from the 19th Century and their scientific production. For her, the handbooks have balanced control and academic freedom. An example of that was José Maria de Avelar Brotero, first professor of Natural Law at São Paulo. He wrote a so criticized handbook, where he was trying to conciliate a materialist ontology and gnoseology and traditional confessional doctrines ${ }^{13}$.

In general, those handbooks were not selected. We can find sources mention traditional authors such as the Portuguese Pascoal de Melo Freire or the swiss Emer de Vattel as handbooks at São Paulo14. But the first handbook that had been written in Brazil by Brotero was not approved by House of Representatives ${ }^{15}$.

9 "Lei de 11 de agosto de 1827. Crêa dous Cursos de sciencias Juridicas e Sociaes, um na cidade de S. Paulo e outro na de Olinda. [...] Art. $7^{\circ}$ Os Lentes farão a escolha dos compendios da sua profissão, ou os arranjarão, não existindo já feitos, com tanto que as doutrinas estejam de accôrdo com o systema jurado pela nação. Estes compendios, depois de approvados pela Congregação, servirão interinamente; submettendo-se porém á approvação da Assembléa Geral, e o Governo os fará imprimir e fornecer ás escolas, competindo aos seus autores o privilegio exclusivo da obra, por dez annos", in https://www2.camara.leg.br/legin/fed/lei_sn/18241899/lei-38401-11-agosto-1827-566698-publicacaooriginal-90225-pl.html.

10 Joaquim Falcão, "Os cursos Jurídicos e a formação do Estado Nacional", in A. Wander Bastos (edit), Os cursos jurídicos e as elites políticas brasileiras: ensaios e criação dos cursos jurídicos no Brasil, Câmara dos Deputados, Brasília, 1978, p. 79.

11 Bistra Stefanova Apostolova, "O debate sobre a fundação dos cursos jurídicos no Brasil (1823-1827). Uma reavaliação”, Varia historia, n. 62, 2017, pp. 419-458. DOI: 10.1590/010487752017000200007 .

12 Sônia Regina Martins de Oliveira, Juristas ao final do império brasileiro (1873-1889): perfis, discursos e modelos a partir do estudo da revista O Direito, Curitiba, UFPR, 2015.

13 Antonio Luiz Machado Neto, História das ideias jurídicas no Brasil, Grijalbo, São Paulo, 1969, p. 25.

14 "Lei de 11 de agosto de 1827. Crêa dous Cursos de sciencias Juridicas e Sociaes, um na cidade de S. Paulo e outro na de Olinda" specially in the attached "Projeto de regulamento ou estatuto para o Curso Juridico pelo Decreto de 9 de Janeiro de 1825, organizado pelo Conselheiro de Estado Visconde da cachoeira, e mandado observar provisoriamente nos Cursos Juridicos de S. Paulo e Olinda pelo art $10^{\circ}$ desta lei". Also the German Friedrich Carl von Savigny and the French Robert Joseph Pothier were between the quoted foreigner authors in the end of XIX century, in Sônia Regina Martins de Oliveira, Juristas ao final do império brasileiro (1873-1889), op. cit., p. 88.

15 Sônia Regina Martins de Oliveira, Juristas ao final do império brasileiro (1873-1889), op. cit. 
José Maria de Avellar Brotero had cumulated functions as professor and secretary for forty three years. He recognized his handbook was written hurriedly. The deputies' verdict said that Brotero's handbook had not linked the issues in harmony. The Commission of Public Education wrote an opinion appointing contradictions in doctrines used and style, with many large and repetitive footnotes ${ }^{16}$.

Many authors have attributed this more to the personal character of Brotero than the book elements, not so far from the common rationality at that time ${ }^{17}$. He was famous for his rhetorical style, "impressionist behaviour" and being the architect to conflicts and insults towards his colleagues.

After the Assembly's verdict in June of 1830, Brotero's handbook was replaced with the Élements de législation naturelle, destinée a l'usage des Éleve de l'école centrale du Pantheon, by J.A. Perreau (1801). In one hand, Brotero did not react to the parliament's decision, neither did the imperial government make any reservations towards his position. On the other hand, Brotero's humour became sharper than before ${ }^{18}$.

Nevertheless, at the end of the Empire, movement to the non-official schooling leaded by positivists and free taught by the liberals had its first light in 1879: superior courses could be freely taught (i.e., not more a state privilege) but programs were established by government ${ }^{19}$.

With the Republic and the rise of Positivism, this trend had more and more space. In the federal government, as important as staff as the military engineer Benjamin Constant advocated for free faculties ${ }^{20}$.

16 "A Comissão de Instrução Pública examinou o compendio de Direito Natural, composto e oferecido a esta augusta Câmara pelo lente do primeiro ano jurídico de S. Paulo, e, observando que não tem ligação e harmonia nas matérias, nem uniformidade no estilo, sendo uma verdadeira compilação de diferentes autores, que não seguiram os mesmos princípios, nem se exprimiram no mesmo estilo; que os raciocínios não têm força de convicção, nem os termos clareza e precisão; que compreende matérias heterogêneas ao Direito Natural, e notas repetidas e muito extensas; é, portanto, de parecer que não seja admitido no Curso Jurídico, devendo-se ensinar o Direito Natural por outro compêndio, que melhor desempenhe a matéria [...] Pac,o da Câmara dos Deputados, 30 de julho de 1830. J. R. Soares da Rocha. A. J. do Amaral. A. Ferreira França".

17 Alberto Venâncio Filho, Das arcadas ao bacharelismo: 150 anos de Ensino Jurídico no Brasil, Perspectiva, São Paulo, 1977, p. 48; Rodrigo Octavio, Foi um dia um convento... Conferência sobre a Faculdade de S. Paulo, Rio de Janeiro, 1936, pp. 16-19.

18 Miguel Reale, "Avellar Brotero, ou a ideologia sob as arcadas", Revista da Faculdade de Direito da USP, n. 50, 1955, pp. 131-169.

19 "Decreto $\mathrm{n}^{\circ}$ 7.247, de 19 de abril de 1879. Reforma o ensino primario e secundario no municipio da Côrte e o superior em todo o Imperio. Art. $1^{\circ} \mathrm{E}^{\prime}$ completamente livre o ensino primario e secundario no municipio da Côrte e o superior em todo o Imperio, salvo a inspecção necessaria para garantir as condições de moralidade e hygiene. [...] Art. 23 o programa porém é estabelecido pelo governo", in https://www2.camara.leg.br/legin/fed/decret/1824-1899/decreto7247-19-abril-1879-547933-publicacaooriginal-62862-pe.html.

20 Dermeval Saviani, "A expansão do ensino superior no Brasil: mudanças e continuidades", Poíesis Pedagógica, n. 8, 2010, pp. 4-17. However, I disagree with the author's affirmation that the Constitution of the state of Rio Grande do Sul official teaching had been suppressed, since in the Constituição Política do Estado do Rio Grande do Sul (1891) we can see that: "Art. 20 - Como chefe supremo do govêrno e da administração, compete ao Presidente, com plena responsabilidade: [...] $25^{\circ}$ - Providenciar sóbre o ensino público primário, gratuíto e livre, ministrado pelo Estado" and "Art. 71 - A Constituição oferece aos habitantes do Estado as 
The constitutional representatives, while discussing the drafts, decided to maintain the official education while also allowing the offering of private teaching. In few words, neither state monopoly nor state absence. Although, this defence of public education is not to be confused with the old imperial centralization or any barrier to free teaching beyond catholic schools, the former official state religion $^{21}$.

The only reference in the Federal Constitution of 1891 (CF/1891) of academic freedom was the prohibition of confessional instruction in public schools and faculties in the catalogue of fundamental rights. Nevertheless, freedom of speech in general was protected ${ }^{22}$.

Meanwhile, in the matter of organization of superior education, the new republican constitution is much more detailed. National Congress was responsible for legislation on superior education, but parliament did not have the monopoly to establish universities anymore. So, not too much different as what was seen in the 1879 reform.

However, in practice the new regime had many difficulties to sustain the constitutional text. Few months later the federal government imposed etát de siège and one of the exceptional measures was the demission of professors ${ }^{24}$.

The turning point started in 1910. There were the first experiments to make all education free in Brazil. The budget law in December 31, after providing all funding to governmental activities inserted an authorization to the Executive

seguintes garantias: [...] § 10 - Será leigo, livre e gratuito o ensino primário ministrado nos estabelecimentos do Estado", in

http://www2.al.rs.gov.br/biblioteca/LinkClick.aspx?fileticket=oknlkK_3Etc\%3d8øtabid=3107. For more details, see Berenice Corsetti, "A construção do cidadão: os conteúdos escolares nas escolas públicas do Rio Grande do Sul na Primeira República”, História da Educação, v. 4, n. 8, 2000, pp. 175-192.

21 Carlos Roberto Jamil Cury, "A desoficialização do ensino no Brasil: a Reforma Rivadávia", Educação Social, v.30, n. 108, 2009, pp. 717-738.

${ }^{22}$ CF/1891: "Art 72 - A Constituição assegura a brasileiros e a estrangeiros residentes no País a inviolabilidade dos direitos concernentes à liberdade, à segurança individual e à propriedade, nos termos seguintes: [...] § $6^{\circ}$ Será leigo o ensino ministrado nos estabelecimentos publicos. [...] § 12 Em qualquer assunto é livre a manifestação de pensamento pela imprensa ou pela tribuna, sem dependência de censura, respondendo cada um pelos abusos que cometer nos casos e pela forma que a lei determinar. Não é permitido o anonimato", in http://www.planalto.gov.br/ccivil_03/Constituicao/Constituicao91.htm.

24 "Decorridos alguns mezes, uma reunião tumultuosa, effectuada na capital federal, suggeriu ao Governo a idéa de declarar esta em estado de sitio, e á sombra de similhante providencia excepcional, deportou elle senadores e deputados, prendeu diversos cidadãos que foram recolhidos a fortalezas, e demittiu até lentes vitalicios do ensino superior da republica. [...] algumas das medidas tomadas pelo governo continuaram a subsistir, ainda depois da amnistia concedida pela Congresso. Por exemplo, a emissão de lentes cathedraticos de Faculdades officiaes. Não me pareceu, entretanto, regular este alvitre, tanto mais grave quanto a demissão mesma fora já um excesso condemnavel, que ninguem poderia justificar com o nosso Estatuto fundamental, bastante claro na restriccão que impõe no $\S 2^{\circ}$ do art. 80 , sem fallar mesmo no que determina pelo art. 74, adiante commentado. Felizmente, a começar de 1895, foram sendo reparados taes erros, voltando os empregados vitalicios a occupar os seus logares", in Felisbello Freire, As Constituicoes dos Estados e a Constituição Federal, Imprensa Nacional, Rio de Janeiro, 1898, p. 238-239. 
branch to reform education and decline any privilege in this matter, granting complete freedom to organize programs ${ }^{25}$.

Few months later the Minister of Justice Rivadávia Corrêa presented the text, after it was approved in parliament as "Organic" Act of Superior and Fundamental Education. The law adopted full freedom and "deofficialization" of education in Brazil. By the law, the federal government exempted the requirement of assimilation to a (public) model institution, which made possible the creation of universities by private entities. The didactic autonomy was reinforced in this act $^{26}$. In his radical vision, academic freedom was the all free possibility to choose their masters, independently of titles and institutions. But in practice the opposite happened: this system gave more autonomy to congregations of professors to organize and explore a soft power in Brazilian society ${ }^{27}$.

In his explanatory statement, Minister Corrêa said how this liberty would free the academic conscience from the scholar's oppression and eliminate governmental tutelage, because in his opinion it was the real problem of the entire Brazilian system of education. Now the Academic senates became responsible for their acts. Thus, Rivadávia Corrêa attributed the compromise to science and a sense of duty to the responsibility as the reverse face of freedom ${ }^{28}$.

25 "Lei no 2.356, de 31 de dezembro de 1910. Fixa a despeza geral da Republica dos Estados Unidos do Brazil para o exercicio de 1911 e dá outras providencias. [...] Art. $3^{\circ}$ Fica o Poder Executivo autorizado: [...] II. A reformar a instrucção superior e secundaria mantida pela União, dando, sob conveniente fiscalização, sem privilegio de qualquer especie: Aos institutos de ensino superior: [...] b) completa liberdade na organização dos programmas dos respectivos cursos, nas condições de matricula, exigindo o exame de admissão para o ingresso em seus cursos, no regimen de exames e disciplina escolar", in http://www.planalto.gov.br/ccivil_03/LEIS/19011929/L2356.htm.

26 "Decreto $n^{\circ}$ 8.659, de 5 de abril de 1911. Approva a lei Organica do Ensino Superior e do Fundamental na Republica: Art. $2^{\circ}$ Os institutos, até agora subordinados ao Ministerio do Interior, serão, de ora em diante, considerados corporações autonomas, tanto do ponto de vista didactico, como do administrativo. [...] Art. $6^{\circ}$ Pela completa autonomia didactica que lhes é conferida, cabe aos institutos a organização dos programmas de seus cursos", in https://www2.camara.leg.br/legin/fed/decret/1910-1919/decreto-8659-5-abril-1911-517247publicacaooriginal-1-pe.html.

27 "[...] com a instauração da República, particularmente através da transferência das formalidades da selec,ão de professores às faculdades, cabendo ao governo apenas sancionar a decisão. Ocorre, portanto, uma espécie de insulamento formal dos procedimentos de acesso aos cargos na docência e, igualmente, nos modos de escolha dos diretores: se no período imperial esses não eram necessariamente parte do corpo professoral, no republicano passam a ser escolhidos entre os membros da congregac,ão. De modo geral, isso vem reforçar a segmentac,ão dos níveis de controle e a consequente diversificação da estrutura de mediação, ou seja, as reformas do regime republicano tornam mais significativos os trunfos associados às relac,ões de reciprocidade internas às diferentes faculdades", Rodrigo da Rosa Bordignon, "As faculdades de direito e o recrutamento de professores de ensino superior na Primeira República", Revista Sociedade e Estado, v. 32, n. 3, 2017, pp. 749-769, p. 757. DOI: 10.1590/s010269922017.3203009.

28 "Liberta a consciência acadêmica da opressão dos mestres, arredada destes a tutela governamental, em cujo passivo se inscrevem todas as culpas da situação periclitante a que chegaram as instituic,ões do ensino, acredito dar um passo para frente com a atual organização. $\mathrm{O}$ que produzir o futuro cairá sob a responsabilidade das congregações [...] livre docência que significa, nada mais, nada menos do que a permissão ao aluno para escolher o seu mestre e a garantia a qualquer cidadão habilitado para lecionar no recinto dos estabelecimentos oficiais [...] A autonomia não se restringiu a uma vantagem exclusiva das congregaçóes (...) é também um direito do professor, quanto ao sistema e método do ensino, que são de sua competência e em que 
This license from federal government caused many federal states to build their own universities, such as São Paulo (1911) and Paraná (1912)29.

Four years later another act ${ }^{30}$ reorganized superior education in the Republic. The federal government returned to establish the courses and finally in $1920^{31}$, federal government created its first university where were gathered Law, Medical and Polytechnic schools. In both laws academic freedom ("autonomia didactica $e$ administrativa") became the cardinal principle of the system of superior education.

The ascension of Getulio Vargas, after the 1930 Revolution that closed the First Republic and established a real universitary system. It was one of the first reforms of the rising regime. The act of 1931 settled on a more centralized model, where all dispositions would need to be discussed within the new National Board of Education. Nonetheless, academic freedom was guaranteed, including alternative approaches according to regional differences ${ }^{32}$.

a iniciativa individual pode dar fecundos resultados" in Rivadavia da Cunha Corrêa, "Lei organica do ensino superior e do fundamental da Republica. Approvada pelo Decreto n. 8.659, de 5 de abril de 1911 (precedida da exposição de motivos)", Revista da Faculdade de Direito da USP, v. 20, 1912. DOI: 10.11606/issn.2318-8227.v20i0p263-301.

29 "[...] as possibilidades de abertura de faculdades livres não surtiram efeitos no período imperial. Exceção pode ser feita à Faculdade Livre de Ciências Jurídicas e Sociais do Rio de Janeiro, formalmente fundada em 1882, por Fernando Mendes de Almeida (1845-1921) e por um "punhado de amigos e admiradores" (Venâncio Filho, 1977: 187). As possibilidades de expansão do quadro institucional do ensino superior vieram com o advento do regime republicano e a manutenção do ensino livre. O efeito imediato é a regionalização da oferta de diplomas jurídicos e a consequente diversificac,ão das modalidades de inserc,ão social e profissional dos pretendentes aos cargos em expansão", Rodrigo da Rosa Bordignon, "As faculdades de direito e o recrutamento de professores de ensino superior na Primeira República”, op. cit, pp. 758-759.

30 "Decreto $\mathrm{n}^{\circ} 11.530$, de 18 de Março de 1915. Reorganiza o ensino secundario e o superior na Republica. Art. $1^{\circ} \mathrm{O}$ Governo Federal continuará a manter os seis institutos de instrucção secundaria e superior subordinados ao Ministerio da Justiça e Negocios Interiores, dando-lhes autonomia didactica e administrativa de accôrdo com as disposições deste decreto", in https://www2.camara.leg.br/legin/fed/decret/1910-1919/decreto-11530-18-marco-1915522019-republicacao-97760-pe.html.

31 "Decreto $\mathrm{n}^{\circ}$ 14.343, de 7 de setembro de 1920. Institue a Universidade do Rio de Janeiro [...] Art. $3^{\circ}$ A $^{\prime}$ Escola Polytechnica do Rio de Janeiro, á Faculdade de Medicina do Rio de Janeiro e á de Direito do Rio de Janeiro será assegurada e autonomia didactica e administrativa", in https://www2.camara.leg.br/legin/fed/decret/1920-1929/decreto-14343-7-setembro-1920570508-publicacaooriginal-93654-pe.html.

32 "Decreto $\mathrm{n}^{\circ}$ 19.851, de 11 de abril de 1931. Dispõe que o ensino superior no Brasil obedecerá, de preferencia, ao systema universitario, podendo ainda ser ministrado em institutos isolados, e que a organização technica e administrativa das universidades é instituida no presente Decreto, regendo-se os institutos isolados pelos respectivos regulamentos, observados os dispositivos do seguinte Estatuto das Universidades Brasileiras [...] Art. $3^{\circ} \mathrm{O}$ regimen universitario no Brasil obedecerá aos preceitos geraes instituidos no presente decreto, podendo, entretanto, admittir variantes regionaes no que respeita á administração e aos modelos didacticos. [...] Art. $9^{\circ}$ As universidades gosarão de personalidade juridica e de autonomia administrativa, didactica e disciplinar, nos limites estabelecidos pelo presente decreto, sem prejuizo da personalidade juridica que tenha ou possa ser atribuida pelos estatutos universitarios a cada um dos institutos componentes da universidade. Paragrapho unico. Nas universidades officiaes, federaes ou estaduaes, quaesquer modificações que interessem fundamentalmente á organizacção administrativa ou didactica dos institutos universitarios, só poderão ser effectivadas mediante sancção dos respectivos governos, ouvido o Conselho Nacional de Educação", in 
After that, the debate had purchased more density, arriving at the constitutional level. As we already saw, there was not a clear link between freedom of speech and academic freedom in constitutional history until now. After the university reform of 1931 the question had arrived in the National Constitutional Assembly of 1933-1934.

\section{ACADEMIC FREEDOM IN THE CONSTITUTION OF 1934}

If we read the Federal Constitution of 1934 (CF/1934), we can think the question was resolved in a simple way. In fact, the chapter on education and culture disposed in article 155 that "is guaranteed the academic freedom (liberdade de cátedra)". ${ }^{33}$ But if we look at the law making debate (Assembleia Nacional Constituinte ${ }^{34}$ ) the question was very more complex ${ }^{35}$.

The issue was discussed in so many rounds ${ }^{36}$. After academic freedom was raised in the first draft, we can see a very strong discussion on the maintenance of this right in constitutional text. So many requirements asked to subtract it, sometimes without a substantiated reason, but sometimes the representatives had justified academic freedom as a consequence of recognizing freedom of speech ${ }^{37}$.

But in general, the reason was the fear that the act of teaching could use this liberty to disseminate alien political theories as fascism and mainly communism in Law Schools38: "The professor's actions can be prejudicial to your

https://www2.camara.leg.br/legin/fed/decret/1930-1939/decreto-19851-11-abril-1931-505837publicacaooriginal-1-pe.html.

33 CF/1934: "TÍTULO V. Da Família, da Educação e da Cultura. CAPÍTULO II. Da Educação e da Cultura. Art. 155 - É garantida a liberdade de cátedra", in http://www.planalto.gov.br/ccivil_03/Constituicao/Constituicao34.htm.

34 The acts of Assembleia Nacional Constituinte (ANC) are all available in Brasil, Annaes da Assembléa Nacional Constituinte. V. XXII [1933], Imprensa Nacional, Rio de Janeiro, 1936. All online volumes online in http://bd.camara.gov.br/bd/handle/bdcamara/13216.

35 "A Constituição de 1934 também inovou ao garantir a liberdade de cátedra, no artigo 155. O artigo final aprovado apenas garantia a liberdade de cátedra, sem trazer nenhum complemento. Os anais da Constituinte de 1933-1934, por outro lado, demonstram que houve uma quantidade significativa de emendas que buscavam restringir ou delimitar essa liberdade", in Laila Maia Galvão, Constituição, educação e democracia: a Universidade do Distrito Federal (1935-1939) e as transformacõoes da Era Vargas, UnB, Brasília, 2017, p. 30.

36 Laila Maia Galvão, "Social constitutionalism in Brazil: The Brazilian Education Association and the writing of the 1934 Constitution," Giornale di Storia costituzionale, n. 40, i. 2, 2020, pp. 241-258.

37 ANC 33/34 - Vol. 4, p. 307: "Os parágrafos $5^{\circ}$ e $6^{\circ}$ tornam-se desnecessários porque os direitos que eles pretendem estabelecer já estão regulados no título que se refere á declaração de direitos e deveres".

38 The National Congress continued to be obsessed with this idea. The Representatives believed more a half of the Law bachelors became communists, as we can read in the discussion of the reform of the National Security Act of 1935. See Diego Nunes, Le "irrequietas leis de segurança nacional". Sistema penale e repressione del dissenso politico nel Brasile dell'Estado Novo (19371945), UniMC, Macerata, 2014, p. 116. 
students". Academic freedom would be something more than freedom of speech and could act against national political traditions ${ }^{39}$.

Another interesting reason to delete academic freedom was the unsuitable legal transplants. In our case, the Representatives had recognized an influence of German Weimar constitution while building the new constitutional text. While some institutions had been adapted to be used in the Brazilian context, others were so specific to the German reality (as they were arguing on academic freedom) and were not necessary in other contexts ${ }^{40}$.

In this sense, members of Assembly started to try alternative statements. There were inclusions of exceptions or conditions to exercise academic freedom, as "excluding doctrines against the ideal of nation" or "forbidden to hurt the students' feelings". When those groups did not change the statement of academic freedom, they added dispositions to Union and federal states' education legislation in order to protect professors of "disturbing influences" 41 . Opposition mocked these restrictions insinuating government had an excessive fear of Karl $\mathrm{Marx}^{42}$. After that, religious belief was proposed as a limitation of academic freedom ${ }^{43}$.

39 ANC 33/34 - Vol. 4, p. 295: "N. 740 D Art 112, § 6. Suprima-se. Justificação. Somos contra a liberdade de cátedra. A ação de um professor poderá ser prejudicial aos seus alunos. Principalmente porque, ao que parece, a liberdade de cátedra estatuída no anteprojeto é mais alguma coisa que a liberdade de pensamento e de palavra. Se não significar mais que isto, não tem razão de ser objeto de dispositivo especial, porque já figura, sob aqueles títulos, na declaração de direitos. O princípio da liberdade de pensamento e de palavra é uma conquista definitiva da nossa cultura e dos nossos costumes políticos. A duvida se estabelece, entretanto, num ponto: será permitido ao corpo docente de uma escola de direito, por exemplo, fazer propaganda declarada do comunismo, ou do fascismo? A resposta só pode ser afirmativa, si preceituarmos a liberdade de cátedra. Como então o anteprojeto declara fora da lei o cidadão que propagar doutrina da qual se exclua a ideia de pátria? O assunto é arduo e digno da atenção dos senhores da comissão. Sala das Sessões, 20 de dezembro de 1933. - Belmiro de Medeiros Silva".

40 ANC 33/34 - Vol. 4, p. 312: "A fonte do título XI do anteprojeto, intitulado da cultura e do ensino, está integralmente no capítulo IV da constituição alemã, que ele as vezes reproduziu numa simples tradução literal. Não há um só artigo ou parágrafo do anteprojeto, que não tenha a sua origem no texto constitucional aludido. Se há, porém, disposições de interesse universal, no Código político germânico, neste assunto de educação e por isto mesmo, merecedoras de adaptação ao Brasil, outras existem, que na Alemanha nasceram, na Alemanha ficaram e só a Alemanha servem, por que são peculiares ás suas necessidades, derivando da sua tradição e da sua história".

${ }^{41}$ ANC 33/34 - Vol. 19, p. 474-478: "Art. Em leis ordinárias da União, dos estados e do distrito federal, propostas pelos conselhos de educação, serão fixadas normas específicas para a organização dos corpos técnicos, docentes e administrativos do aparelho educacional, com o fim de libertá-lo de quaisquer influencias perturbadoras, e assegurar ao seu pessoal, em regime próprio, as melhores condições de recrutamento e o máximo de estímulos permanentes a sua especialização e eficiência”.

42 ANC 33/34 - Vol. 9, p. 375: "Mas não é só. Vejamos este dispositivozinho sobre a liberdade de cátedra: "é garantida a liberdade de cátedra, sem ofensa aos alunos, por adotarem opinião diferente, excluída toda doutrinação contrária á ideia de patria". Como se vê, o reacionarismo não contente em colocar fora da lei os partidos de caráter socialista, quer extender ainda essa proibição á própria cátedra do magistério superior do país. Convenhamos que já é temer demasiadamente as ideias de Karl Marx..."

43 ANC 33/34 - Vol. 10, p. 446-447: "Art. L. É garantida a liberdade de cátedra, nas escolas públicas, não podendo o professor ferir os sentimentos de quem quer que seja; pregar doutrinas hostis ao regime e forma de governo adotados nesta constituição e nem tratar de assuntos 
Some groups had the desire to affirm all freedom to arts and sciences ${ }^{44}$ because constitution must protect values in a social politic formation. And after all motions to add some limitations to academic freedom, they required an amendment to exclude any and all restrictions ${ }^{45}$. The parliamentary acts do not clearly show the tendencies, but we can observe that every time other representatives had joined the group that was defending academic freedom and was gathering more and more firms in the amendment's requests. According to Laila Galvão, the compromise was to accept the amendment to Union and States by board of education regulate specific situations ${ }^{46}$.

However, it wasn't mean real respect, in practice. As we have seen in the First Republic, under Vargas professors also lost their positions, and were even arrested. The first reason was the criticism of professors from the new University of Federal District (UDF), at Rio de Janeiro, against integralists (the Brazilian 'fascist' movement) and with particular intensity with the support of the Freedom National Alliance (Aliança Nacional Libertadora), an antifascist organization. ${ }^{47}$

The Catholics also were in conflict with some professors, in virtue of the positions of Anísio Teixeira, at that time UDF's rector (today recognized as the one of the biggest educators in Brazil). He was contrary to religious education in public schools. And also, Catholics had an anti-Communist concern and they accused professors to support of "radical ideologies"48.

Three professors served jail time: Hermes Lima, Edgard Rabelo and Leônidas Rezende, the first one a jurist. Some documents point towards the military as the requesters of these prisons. According to Laila Galvão, reading journals from that time, it is possible to see these prisons as a general demand in society, from Catholic Church to press. The fear was the "communist conquest" of "young hearts"49.

Francisco Campos, at that time Secretary of Education in the Federal District, in one of the last actions before he became Minister of Justice of Estado Novo (a new authoritarian regime led by Vargas) ordered to professors of UDF to do preliminary discourses in their lectures against communism. Galvão appointed there are not sources to affirm if professors obeyed or not; but it was a clear attack against academic freedom in the period of the Constitution of 1934 .

religiosos. Vol. 10, p. 446-447: Foi aproveitado, com modificação para melhor, o assunto do $\S 6^{\circ}$ do art. 112, garantido-se a liberdade de cátedra, porém, com algumas restrições”.

44 ANC 33/34 - Vol. 19, p. 474: "N 889 Art. 111. São livres as artes e as ciências".

45 ANC 33/34 - Vol. 19, p. 478: "N. 1.144. Ao $\S 6^{\circ}$ do art. 11 título XI - em lugar da vírgula depois da palavra cátedra, faça-se ponto final, e suprima-se o que mais segue. Sala das sessões, 21 de dezembro de 1933. - Edgard Sanches. - Abelardo Marinho. - Attila Amaral. - Homero Sanches. - Zoroastro Gouveia. - Lacerda Werneck. - Acursio Torres. - Vasco de Toledo. - Acyr Medeiros".

46"O acordo feito ao final foi de que quaisquer regulamentac,ões à liberdade de cátedra deveriam ser estabelecidas no Plano Nacional de Educação. O resultado final foi, portanto, um artigo constitucional prevendo a liberdade de cátedra sem quaisquer restric,ões", in L. Maia Galvão, Constituição, educação e democracia, op. cit., p. 30.

47 L. Maia Galvão, Constituição, educação e democracia, op. cit., p. 101.

48 L. Maia Galvão, Constituição, educação e democracia, op. cit., p. 105.

49 L. Maia Galvão, Constituição, educação e democracia, op. cit., p. 128. 
Francisco Campos himself was an assistant professor at UDF and probably antiCommunist propaganda should have been the usual ${ }^{50}$.

\section{ACADEMIC FREEDOM BETWEEN AUTHORITARIANISM AND DEMOCRACY: CONSTITUTIONS OF 1937, 1946, 1967 AND 1969}

As minister of justice, Francisco Campos gained more expression in this debate, since he himself had written the Constitution of 1937 who installed the Estado Novo. The rule of academic freedom was retired to the new constitutional text, in place to the mention of 1934 constitution. These options in a dictatorship system meant not only to sustain the current model of education, but an increase in repression ${ }^{51}$.

In fact, the Federal Constitution of 1937 (CF/1937) did contain a freedom of speech clause ${ }^{52}$. But different than the precedent statements the text provided limits to that freedom, as designated by the law. It is important to clarify that in that period Parliament was closed and the legislative activity was made directly by the president with the assistance of the ministers ${ }^{53}$. And in that period no freedoms were respected, including freedom of speech. First by national security laws $^{54}$, after during the WWII ${ }^{55}$.

The redemocratization following the end of dictatorship in 1945 started a new constitutional process, and the federal Constitution of 1946 (CF/1946) reinstated academic freedom as a guarantee 56 . However, when the military dictatorship arose in 1964, one of the main measures in the first Institutional Act 57 was to suspend many constitutional guarantees, such as tenure in university ${ }^{58}$. That was confirmed by the AI- $2^{59}$.

50 L. Maia Galvão, Constituição, educação e democracia, op. cit., pp. 165-166.

51 L. Maia Galvão, Constituição, educação e democracia, op. cit., p. 154.

52 CF/1937: "Art 122 - A Constituição assegura aos brasileiros e estrangeiros residentes no País o direito à liberdade, à segurança individual e à propriedade, nos termos seguintes: [...] 15) todo cidadão tem o direito de manifestar o seu pensamento, oralmente, ou por escrito, impresso ou por imagens, mediante as condições e nos limites prescritos em lei", in http://www.planalto.gov.br/ccivil_03/constituicao/constituicao37.htm.

53 Diego Nunes, "Legislative Proceedings outside Parliament in Authoritarian States. The Case of the 1930 Italian and 1940 Brazilian Criminal Codes", Beiträge zur Rechsgeschichte Österreichs, v. 3, n. 2, 2013, pp. 520-527. DOI: 10.1553/BRGOE2013-2s520. A complete discussion, included the role of single jurists as lawgivers in dictatorships in Diego Nunes, "Processo legislativo para além do parlamento em Estados autoritários: uma análise comparada entre os códigos penais italiano de 1930 e brasileiro de 1940", Sequência, v. 37, n. 74, 2016, pp. 153-180. DOI: 10.5007/2177-7055.2016v37n74p153.

54 See D. Nunes, Le "irrequietas leis de segurança nacional”, op. cit.

55 DECRETO No 10.358, DE 31 DE AGOSTO DE 1942. Declara o estado de guerra em todo o território nacional: "Art. $2^{\circ} \mathrm{Na}$ vigência do estado de guerra deixam de vigorar desde já as seguintes partes da Constituição: [...] Art. 122, n. 15, no que concerne ao direito de manifestação de pensamento", in http://www.planalto.gov.br/ccivil_03/decreto/1930-1949/D10358.htm.

56 CF/1946: "Art 168 - A legislação do ensino adotará os seguintes princípios: [...] VII - é garantida a liberdade cátedra", de in http://www.planalto.gov.br/ccivil_03/constituicao/constituicao46.htm.

57 The Atos Institucionais (AI) were a kind of extra or supra constitutional law enacted by the Military Board during the Militar Dictatorship in Brazil. Because of that they were called 
The dictatorship tried to create an atmosphere of normality after the first moment of tension and proposed a Federal Constitution in 1967 (CF/1967). In fact, it provided in text academic freedom ${ }^{60}$. But a year after that, a new and sharper Institutional Act was enacted ${ }^{61}$. The AI-5 gave the possibility to military in power to fire or retire professors. For example, the former Brazilian president Fernando Henrique Cardoso was an example of this persecution. He became professor of Political Sciences at University of São Paulo in 1968, but in April

"anticonstitution" by Ulysses Guimarães, after president of the National Constitution Assembly, in
Cristiano Paixão, "Direito, politica, autoritarismo e democracia no Brasil: da Revolução de 30 à
promulgação da Constituição da República de 1988", Araucaria. Revista Iberoamericana de
Filosofía, Politica y Humanidades, n. 26, 2011, pp. 146-169. All Als can be found in
http://www4.planalto.gov.br/legislacao/portal-legis/legislacao-historica/atos-institucionais.

58 Ato Institucional $n^{\circ} 1$, de 9 de abril de 1964. Dispõe sobre a manutenção da Constituição Federal de 1946 e as Constituições Estaduais e respectivas Emendas, com as modificações instroduzidas pelo Poder Constituinte originário da revolução Vitoriosa: "Art. $7^{\circ}$ - Ficam suspensas, por seis (6) meses, as garantias constitucionais ou legais de vitaliciedade e estabilidade. $\S 1^{\circ}$ - Mediante investigação sumária, no prazo fixado neste artigo, os titulares dessas garantias poderão ser demitidos ou dispensados, ou ainda, com vencimentos e as vantagens proporcionais ao tempo de serviço, postos em disponibilidade, aposentados, transferidos para a reserva ou reformados, mediante atos do Comando Supremo da Revolução até a posse do Presidente da República e, depois da sua posse, por decreto presidencial ou, em se tratando de servidores estaduais, por decreto do governo do Estado, desde que tenham tentado contra a segurança do Pais, o regime democrático e a probidade da administração pública, sem prejuízo das sanções penais a que estejam sujeitos", in http://www.planalto.gov.br/ccivil_03/AIT/ait-01-64.htm.

59 Ato Institucional $\mathrm{n}^{\circ}$ 2, de 27 de outubro de 1965. Mantem a Constituição Federal de 1946, as Constituições Estaduais e respectivas Emendas, com as alterações introduzidas pelo Poder Constituinte originário da Revolução de 31.03.1964, e dá outras providências: "Art. 14 - Ficam suspensas as garantias constitucionais ou legais de vitaliciedade, inamovibilidade e estabilidade, bem como a de exercício em funções por tempo certo. Parágrafo único - Ouvido o Conselho de Segurança Nacional, os titulares dessas garantias poderão ser demitidos, removidos ou dispensados, ou, ainda, com os vencimentos e as vantagens proporcionais ao tempo de serviço, postos em disponibilidade, aposentados, transferidos para a reserva ou reformados, desde que demonstrem incompatibilidade com os objetivos da Revolução", in http://www.planalto.gov.br/ccivil_03/AIT/ait-02-65.htm.

60 CF/1967: "Art 168 - A educação é direito de todos e será dada no lar e na escola; assegurada a igualdade de oportunidade, deve inspirar-se no princípio da unidade nacional e nos ideais de liberdade e de solidariedade humana. [...] VI - é garantida a liberdade de cátedra", in http://www.planalto.gov.br/ccivil_03/Constituicao/Constituicao67.htm.

61 Ato Institucional $\mathrm{n}^{\circ} 5$, de 13 de dezembro de 1968. São mantidas a Constituição de 24 de janeiro de 1967 e as Constituições Estaduais; O Presidente da República poderá decretar a intervenção nos estados e municípios, sem as limitações previstas na Constituição, suspender os direitos políticos de quaisquer cidadãos pelo prazo de 10 anos e cassar mandatos eletivos federais, estaduais e municipais, e dá outras providências: "Art. $6^{\circ}$ - Ficam suspensas as garantias constitucionais ou legais de: vitaliciedade, inamovibilidade e estabilidade, bem como a de exercício em funções por prazo certo. $\S 1^{\circ}$ - O Presidente da República poderá mediante decreto, demitir, remover, aposentar ou pôr em disponibilidade quaisquer titulares das garantias referidas neste artigo, assim como empregado de autarquias, empresas públicas ou sociedades de economia mista, e demitir, transferir para a reserva ou reformar militares ou membros das polícias militares, assegurados, quando for o caso, os vencimentos e vantagens proporcionais ao tempo de serviço. $\S 2^{\circ}-\mathrm{O}$ disposto neste artigo e seu $\S 1^{\circ}$ aplica-se, também, nos Estados, Municípios, Distrito Federal e Territórios", in http://www.planalto.gov.br/ccivil_03/ait/ait-05-68.htm. 
$1969 \mathrm{Mr}$. Cardoso was mandatorily retired based on a decree, called at that time the "universities' AI-5"62.

To adapt to the new exceptional situation in 1969 was enacted an amendment to the constitution of 1967 (EC 1/1969), including the measures present in AI-5. Academic freedom was recognized with a constitutional restriction ${ }^{63}$ : If an abuse of this fundamental right would have happened a suspension from two to ten years would be applied ${ }^{64}$.

\section{DEVELOPMENTS OF ACADEMIC FREEDOM IN THE BRAZILIAN CONSTITUTIONAL THOUGHT}

After this normative overview, my point is to compare these legal rules to legal thought. The goal is to see how jurists realized and reacted to those constitutional movements. In general, the tradition of Brazilian jurists is liberal. But it is interesting to test how liberal they really were by analysing their comments to the constitutional texts on academic freedom.

In 1857 Jose Antonio Pimenta Bueno, Marquis of São Vicente wrote the most important treatise on constitutional law in the Brazilian empire. He did not talk about academic freedom in specific but alerted "freedom is always one and the same issue" even we could see particular aspects. In this way, Pimenta Bueno discussed some modalities of freedom; for us, it is interesting to look at freedom of thought ${ }^{65}$.

Then, he had started explaining the fundamental criterium of publicity and press. For him, this was the most powerful way to spread communication and a

62 "Decreto-Lei no 477, de 26 de Fevereiro de 1969. Define infrações disciplinares praticadas por professores, alunos, funcionários ou empregados de estabelecimentos de ensino público ou particulares, e dá outras providências. Art. $1^{\circ}$ Comete infração disciplinar o professor, aluno, funcionário ou empregado de estabelecimento de ensino público ou particular que: [...] VI - Use dependência ou recinto escolar para fins de subversão ou para praticar ato contrário à moral ou à ordem pública. $\S 1^{\circ}$ As infrações definidas neste artigo serão punidas: I - Se se tratar de membro do corpo docente, funcionário ou empregado de estabelecimento de ensino com pena de demissão ou dispensa, e a proibição de ser nomeado, admitido ou contratado por qualquer outro da mesma natureza, pelo prazo de cinco (5) anos", in https://www2.camara.leg.br/legin/fed/declei/19601969/decreto-lei-477-26-fevereiro-1969-367006-publicacaooriginal-1-pe.html.

63 EC 1/69: "Art. 176. A educação, inspirada no princípio da unidade nacional e nos ideais de liberdade e solidariedade humana, é direito de todos e dever do Estado, e será dada no lar e na escola. [...] VII - a liberdade de comunicação de conhecimentos no exercício do magistério, ressalvado disposto no artigo in http://www.planalto.gov.br/ccivil_03/Constituicao/Emendas/Emc_anterior1988/emc01-69.htm.

64 EC 1/69: "Art. 154. O abuso de direito individual ou político, com o propósito de subversão do regime democrático ou de corrupção, importará a suspensão daqueles direitos de dois a dez anos, a qual será declarada pelo Supremo Tribunal Federal, mediante representação do Procurador Geral da República, sem prejuízo da ação cível ou penal que couber, assegurada ao paciente ampla defesa".

65 "§ 5.o - Das diversas especies ou relações da liberdade. 540. - A liberdade é sempre uma e a mesma, mas como ella póde ser considerada em differentes relações, por isso costuma-se dividi-la ou classifica-la como liberdade do pensamento e sua communicação, de consciencia ou religião, de locomoção, viagem ou emigração, de trabalho ou industria, de contractar e de associação", José Antonio Pimenta Bueno (Marquis of São Vicente), Direito publico brazileiro e analyse da Constituição do Imperio, Typ. Imp. e Const. de J. Villeneuve e C., Rio de Janeiro, 1857, p. 394. 
character of free people and govern ${ }^{66}$. On books, the Marquis of São Vicente affirmed the benefits of the circulation of knowledge to release the nation from darkness ${ }^{67}$.

To finish the debate, Pimenta Bueno defended the existence of a Ministry of Education in the empire ${ }^{68}$. He was an also important politician, former judge, governor, chancellor, at that point senator and subsequently member of the State Council and Prime-Minister. For him it was the best way to accomplish the constitutional promise to guarantee a superior education ${ }^{69}$.

Carlos Maximiliano in commentaries on the Brazilian constitution of 1891 had utilized, in order to explain freedom of speech, the case of Socrates in Ancient Greece. It was interesting to him to present the role of a "teacher" who preferred death to silence ${ }^{70}$. Maximiliano went on to become a judge of the

66 "§ 1.o - Da liberdade do pensamento. 541. - A liberdade do pensamento em si mesmo, emquanto o homem não manifesta exteriormente, emquanto o não communica, está fóra ele todo o poder social, até então é do dominio sómente do proprio homem, de sua intelligencia e de Deos. A sociedade, ainda quando quizesse, não tinha. meio algum de penetrar nessa esphera intellectual, sua leis não chegão até la. [...] §3.o - 543. - [...] De todos os meios de communicação a imprensa é sem duvida o mais amplo e poderoso, sobrexcede mesmo a gravura e a lithographia. $\mathrm{E}^{\prime} \mathrm{um}$ instrumento maravilhoso, que leva as idéas ou opiniões a todas as localidades, que as apresenta a todos os olhos, atravessa os Estados, percorre o mundo, consegue o assenso de muitos, porque communica-se com todos, porque põe em movimento o pensar de milhões de homens. E' por isso mesmo um instrumento poderoso, cujo uso e liberdade é caracteristica dos povos e governos livres", J. A. Pimenta Bueno, Direito publico brazileiro e analyse da Constituição do Imperio, op. cit., p. 395.

67 "544. Os beneficios da imprensa litteraria ou industrial são immensos, incommensuraveis. E' ella quem tem promovido a civilisação, desenvolvido as faculdades humanas, fertilisado os conhecimentos, o trabalho, a industria, a riqueza. Seu echo propala as invenções apenas descobertas, noticia os processos, os methodos, os progressos de todas as artes e as sciencias, uma fonte perenne de luzes e consequentemente de bem-ser social. Emfim, posto que indirectamente, ella concorre com grande força para a liberdade dos homens, porque não póde haver escravidão desde que o espírito do povo tem conseguido illustração; a escravidão só se mantém no assento da ignorância. A liberdade da imprensa litteraria ou industrial deve ser amplamente franqueada, não só aos nacionaes, como aos estrangeiros; a livre expressão da intelligencia, desde que não se envolve no governo politico do paiz, pertence ao homem porque é homem, qualquer que seja sua nacionalidade", J. A. Pimenta Bueno, Direito publico brazileiro e analyse da Constituição do Imperio, op. cit., pp. 395-396.

68 "Do direito á instrucção [...] § 2o. - Dos collegios e universidades. 607. - A constituição garante tambem, posto que não seja gratuitamente, a creação dos estudos preparatorios e superiores, que são indispensáveis para muitos, para as profisssões mais elevada, e para os serviços publicas mais importantes; é pois necessario cumprir a promessa constitucional. Tratando do ministerio do imperio, da necessidade de subdividi-lo, e de crear um ministerio especial da instrucção publica, já expuzemos algumas observações, que fôra superfluo reproduzir aqui", J. A. Pimenta Bueno, Direito publico brazileiro e analyse da Constituição do Imperio, op. cit., p. 441.

69 "E' tambem de mister olhar com olhos fixos para a instrucção publica e para os cultos. Esse ministerio deverá desenvolver a intelligencia nacional, e apperfeiçoar os costumes. A acção da intelligencia e das virtudes é superior á acção das leis, consegue o que estas não podem conseguir. Será essa divisão um passo dado para a creação de uma universidade, para adopção de um plano de educação nacional, não na côrte sómente, sim em todo o imperio", J. A.Pimenta Bueno, Direito publico brazileiro e analyse da Constituição do Imperio, op. cit., p. 259.

70 "Socrates achava preferivel - ficar sem sol o universo do que privada da liberdade da palavra a Republica. Prégava no deserto. Elle próprio pagou com a vida a audácia de evangelizar idas não aceitas pelos dominadores", Carlos Maximiliano, Comentários à constituição brasileira de 1891, Senado Federal, Brasília, [1918] 2005, p. 707. 
Brazilian Supreme Court. There, he judged many cases related to anarchism, and maybe for that recognized the possibility to debate anarchism while not inciting violence ${ }^{71}$.

Pontes de Miranda in his comments to the Constitution of 1937 was the first scholar to discuss academic freedom in detail ${ }^{72}$. His comments were about the text of the Constitution of 1934, because as we see above academic freedom was not mentioned in the 1937 text. This author is important here, for his having commented the Brazilian constitutions of 1934, 1937, 1946 and 1967.

For him, the nations must "activate", not "intervene" in education. People must exercise science freely. The role of state is to provide special guarantees for scientists in order to develop their free spirit. The contrary would be the Hobbes' Leviathan ${ }^{73}$. In a strictly legal way, he advocated the Constitution did not present any limitations to academic freedom. Every violation would be protected by a "mandado de segurança"74 remedy, more or less similar to common law mandamus and the Latin-American (Argentinian and Mexican) "recurso de amparo"75.

However, he did not consider academic freedom as a fundamental right but just as an institutional guarantee. Any act of parliament could eliminate it and Senate would cancel actions of the Executive branch against its free exercise ${ }^{76}$. As we saw before, any of those protections were not enough to protect professors in the Vargas age.

In other way, in his comments to the Constitution of 1946, Pedro Calmon advocated the possibility to see academic freedom as a longa manus of freedom of speech $^{77}$. For him the State cannot orient science and have to protect academic

71 C. Maximiliano, Comentários à constituição brasileira de 1891, op. cit., p. 712 .

72 F. Pontes de Miranda, Comentários à Constituição Federal de 10 de novembro de 1937, Pongetti, Rio de Janeiro, 1938, p. 411.

73 F., Comentários à Constituição Federal de 10 de novembro de 1937, op. cit., p. 412.

74 "Garante-se no art. 155 a liberdade de cátedra, que se refere tanto ao conteúdo quanto ao método de ensino. Um dos limites é o do art. 149: 'num espirito brasileiro a consciência da solidariedade humana'; porém o art. 113,4) e 5), mostra que não criaram as restrições à liberdade de pensamento que espíritos facciosos pretendem existam na constituição. O remédio para a proteção constitucional da liberdade de cátedra é o mandado de segurança de que trata o art. 113, 33)", F. Pontes de Miranda, Comentários à Constituição Federal de 10 de novembro de 1937, op. cit., p. 411.

75 Gabriel Faustino Santos, Diego Nunes, "O contexto histórico de formação do mandado de segurança e o redimensionamento jurídico da justiça no Brasil da Primeira República", $3^{\circ}$ Seminário Internacional Democracia e Constitucionalismo: novos desafios na era da globalização, Perugia, Universidade de Perugia, Itália, 2016, Anais de constitucionalismo, transnacionalidade e sustentabilidade, 2016, v. 3. p. 208-227.]

76 "A liberdade de cátedra não é um direito fundamental; pelo menos não no é ainda. É uma garantia institucional. Não pode ser suprimida por lei ordinária. Não é preciso que haja direito subjetivo violado para que exista infração da constituição no artigo 155; e é possível a atuação do Senado Federal (art. 91, II)", F. Pontes de Miranda, Comentários à Constituição Federal de 10 de novembro de 1937, op. cit., p. 413.

77 "Este postulado poderia ter sido inscrito entre os direitos e garantias do cidadão. É um prolongamento da liberdade de pensar e de crer, na consagração da independência mental do professor, que não recebe do Estado - incompetente para isto - a orientação científica, nem pode circunscrever o ensino - fundado na exposição dos autores, apurada nos laboratórios, 
freedom as a liberal style and a safeguard to intellectual autonomy and professors' dignity ${ }^{78}$. Adding to that, he emphasized the life tenure of full professor's position ${ }^{79}$.

Themistocles Cavalcanti 80 was more emphatic to affirm academic freedom as a constitutional guarantee. This safeguard did not admit any restrictions nor limits. Abuses could be punished by administrative sanctions but needed to be linked to the freedom of speech as a constitutional right.

Pontes de Miranda repeated exactly the same words he had written about the Constitution of 1934 to explain the academic freedom in the 1946 constitutional system ${ }^{81}$, just adding possibility of habeas corpus, maybe because he remembered the prisons by the Vargas regime. Nevertheless, he added an important comment on the professor's tenure: it was ironic, justifying an old error (demissions and forced retirements during Vargas era) by committing a new one (life tenure to professors) ${ }^{82}$. He did not explain more, but he commented be contrary to the imposition of public tender to professors because states must search professors, not the contrary ${ }^{83}$... He was also a mathematician (famous for discussing with Einstein on the theory of relativity) and maybe for that expressed his concerns about the issue ${ }^{84}$.

In the first years of military dictatorship, but in comments to the Constitution of 1946, whose rights and guarantees had been suspended by AI-1 and AI-2, Claudio Pacheco used similar terms to Pontes de Miranda: academic freedom was not a constitutional right but an institutional guarantee. However,

desenvolvida nos sistemas didáticos - a conveniências estranhas ao seu próprio fim, que é ensina", Pedro Calmon, Curso de direito constitucional brasileiro: constituição de 1946, Freitas Bastos, Rio de Janeiro, 1947, pp. 368-369.

78 "A liberdade de cátedra é uma segurança de autonomia intelectual e dignidade do mestre. Corresponde ao estilo liberal do regime, acentuado dogmaticamente no art. 173 (que aliás copia o art. 142 da Const. alemã de 1919): As ciências, as letras e as artes são livres. E acrisolado no art. 174: O amparo à cultura é dever do Estado", P. Calmon, Curso de direito constitucional brasileiro op. cit., p. 369.

79 P. Calmon, Curso de direito constitucional brasileiro op. cit., pp. 367-368, n. 6.

80 Themistocles Brandão Cavalcanti, A constituição federal comentada, Vol. IV, 3 ed., José Konfino, Rio de Janeiro, 1959.

81 F. Pontes de Miranda, Comentários à Constituição de 1946, T. VI, 3 ed., Borsoi, Rio de Janeiro, 1960, pp. 218-219.

82 "13) VITALICIEDADE - Vitaliciedade, tal como a dos juízes. Revide professoral à poda reacionária de professores, por volta de 1935-1936. Erro de ontem engendrando erro de hoje. Os atos dos povos, bons ou maus, os acompanham", F. Pontes de Miranda, Comentários à Constituição de 1946, op. cit., p. 218.

83 "12) CONCURSO PARA O ENSINO SUPERIOR - No próprio ensino superior livre exige-se o concurso de provas e títulos. O mandarinato professoral brasileiro está satisfeito: afastaram-se os sábios estrangeiros... e os nacionais, tão raros. Sábios não pleiteam cargos; sábios são rogados, seduzidos, cercados de todas as comodidades para que imigrem ou, sendo nacionais, aceitem as canseiras, tão mal pagas, do professorado nacional, sempre ligado a outra profissão que a de ensinar", F. Pontes de Miranda, Comentários à Constituição de 1946, op. cit., p. 218.

84 Djacir Menezes, "Hans Kelsen e Pontes de Miranda", Revista de Ciência Política, v. 25, n. 1, 1982, pp. 18-25 and Humberto Gomes De Barros, "Pontes de Miranda: o Direito como Ciência Positiva”, Informativo Jurídico Biblioteca Min. Oscar Saraiva, n. 4, 1992., pp. 37-43. 
for Pacheco, it was not linked to freedom of speech, but freedom of education. It was not an immunity, but a freedom of word during a lecture ${ }^{85}$.

On the Constitution of 1967, Roberto Magalhães compared the old text of 1946, to the draft of and current constitutional text. For him, in that moment, academic freedom had a more restricted meaning, in similar terms as Pacheco wrote above: freedom to teach and learn and nothing more ${ }^{86}$.

Silences in scholars were more significant than their words: every question not discussed meant an interdict issue. Commenting the Constitution of 1967 after the amendment of 1969 , Pontes de Miranda ${ }^{87}$ repeated again his words on the 1934 system: it is possible to be liberal on the books, only if they ignore the reality outside.

\section{CONCLUSION}

Nowadays, with the Federal Constitution of 1988 (CF/1988) we have a large discipline of academic freedom. Even though the dispositions are not located together on the fundamental rights list, legal scholarship and tribunals have recognized the same status to guarantees dispersed in the text ${ }^{88}$. The principles of education consist of freedom to learn, teach, research and propagate thought in pluralistic ways, and universities have didactic and scientific autonomy ${ }^{89}$.

In the last thirty years, we have lived in a stable period for academic freedom. Now looking at it through a historical point of view, it is clear there was an oasis regarding our constitutional history. At least, in the last eighty years, when academic freedom arrived in the Brazilian constitutions, the issue was very disputed by many sectors in society: politicians, clergy, press and civil society at

85 "[A] liberdade de cátedra, que se pode classificar mais seguramente como uma garantia institucional do que como um direito fundamental. A liberdade de cátedra pode ser entendida como um dos desdobramentos da liberdade geral de educação [...] ainda não se trata de imunidade [...] Por outro lado, a liberdade de cátedra [...] não significa monopólio de cátedra, mas sim, liberdade de palavra concedida ao professor ao ministrar suas aulas", Cláudio Pacheco, Tratado das constituições brasileiras, Vol. XII, Freitas Bastos, Rio de Janeiro, 1965, pp. 294-295.

86 "A manutenção de expressão 'liberdade de cátedra', não autoriza outra interpretação senão a de significar liberdade de ensino na sua ampla acepção de liberdade de aprender e ensinar", Roberto Barcellos de Magalhães. Constituição Federal de 1967 comentada, T. II, José Konfino, Rio de Janeiro, 1967, p. 530.

87 Francisco Pontes de Miranda, Comentários à Constituição de 1967: com a Emenda n. 1 de 1969, Revista dos Tribunais, São Paulo, 1970.

88 CF/1988: "Art. $5^{\circ}$ Todos são iguais perante a lei, sem distinção de qualquer natureza, garantindo-se aos brasileiros e aos estrangeiros residentes no País a inviolabilidade do direito à vida, à liberdade, à igualdade, à segurança e à propriedade, nos termos seguintes: [...] $\S 2^{\circ}$ Os direitos e garantias expressos nesta Constituição não excluem outros decorrentes do regime e dos principios por ela adotados, ou dos tratados internacionais em que a República Federativa do Brasil seja parte", in http://www.planalto.gov.br/ccivil_03/constituicao/constituicao.htm.

89 CF/1988: "CAPÍTULO III. DA EDUCAÇÃO, DA CULTURA E DO DESPORTO. Seção I. DA EDUCAÇÃO. Art. 206. O ensino será ministrado com base nos seguintes princípios: [...] II liberdade de aprender, ensinar, pesquisar e divulgar o pensamento, a arte e o saber; III pluralismo de idéias e de concepções pedagógicas, e coexistência de instituições públicas e privadas de ensino; [...] Art. 207. As universidades gozam de autonomia didático-científica, administrativa e de gestão financeira e patrimonial, e obedecerão ao princípio de indissociabilidade entre ensino, pesquisa e extensão". 
large. All attempts of protecting academic freedom recognize our difficulties in granting effectiveness to the principle.

In general, we can conclude in legislative terms that the most interesting constitutional regulation of academic freedom in Brazil was that of the CF/1934, if we exclude the current constitution. As we observed in the preparatory acts, there was a very articulate discussion and vast discipline on the issue. The other constitutions either ignored the question, leaving the regulation to the Legislative branch or - during authoritarian periods - created limitations to the exercise of that guarantee.

However, in terms of legal thought the explanation is more complex. It is complicated to out any of those jurists as authoritarian; in opposition, in general their comments were liberal. We can see a liberal mask, but at all times they had been recognizing limits and restrictions imposed by politics. Maybe it was the norm if we think the behaviour of jurists in general, but here those same jurists were professors. Perhaps the perception of Pontes de Miranda, who understood teaching as a favour because a second position (after lawyer, judge and other legal positions) could help us realize the precariousness of the condition of Brazilian academia, at least in Law schools.

Looking in detail our legal scholars and their treatises on Brazilian constitutions they spoke sparingly on this issue. As we see, silences could be important signals, as these men have had positions in governments, or needed more autonomy if they were judges, or just did not create polemics in their texts. For that reason, in Constitutional History it is important - as Laila Galvão90 did to conjugate microscopic views with macroscopic approaches, as I proposed here.

Enviado el (Submission Date): 18/04/2020

Aceptado el (Acceptance Date): 23/06/2020

90 "No entanto, a história constitucional aqui trabalhada alcanc,ou não apenas macro narrativas e ideologias políticas, mas também dispositivos muito específicos e particulares desses textos normativos. Uma discussão sobre como redigir o dispositivo que garantia a liberdade de cátedra, sobre a alteração de disposições sobre funcionários públicos envolvendo puniç,ões e acumulaç,ões de cargos ou sobre a autonomia política do Distrito Federal também faziam parte desse emaranhado conectando direito e política. A investigacão de questões aparentemente miúdas é capaz, em determinados casos, de expor também conflitos dignos de uma análise mais detida no campo da história constitucional", Laila Maia Galvão, Constituição, educação e democracia, op. cit., p. 215. 